\title{
THE PERFORMANCE OF BANKS IN A DEVELOPING COUNTRY: HAS COVID-19 MADE ANY DIFFERENCE?
}

\author{
DOI: 10.17261/Pressacademia.2021.1429 \\ PAP- V.13-2021(18)-p.94-95
}

\author{
Muhanned Obeidat ${ }^{1}$, Ahmad Tarawneh², Mohammad Khataibeh ${ }^{3}$, Ghassan Omet ${ }^{4}$ \\ ${ }^{1}$ University of Jordan, Department of Finance, Amman, Jordan. \\ mu.obeidat@ju.edu.jo, ORCID:0000-0002-8988-1291 \\ ${ }^{2}$ University of Jordan, Department of Finance, Amman, Jordan. \\ ah.altarawneh@ju.edu.jo, ORCID:0000-0002-5833-1887 \\ ${ }^{3}$ University of Jordan, Department of Finance, Amman, Jordan. \\ khataybeh@ju.edu.jo, ORCID:0000-0003-3599-903X \\ ${ }^{4}$ University of Jordan, Department of Finance, Amman, Jordan. \\ gomet@ju.edu.jo, ORCID:0000-0002-8988-1387
}

To cite this document

Obeidat, M., Khataibehrawneh A., M., Omet, G. (2021). The crowding-out effect in a small developing economy: a lesson from Covid-19. PressAcademia Procedia (PAP), V.13, 94-95.

Permanent link to this document: $\underline{\text { ttp://doi.org/10.17261/Pressacademia.2021.1429 }}$

Copyright: Published by PressAcademia and limited licensed re-use rights only.

\section{ABSTRACT}

Purpose- The implications of COVID-19 still evolves. However, it has become clear that the virus has hit the supply and demand sides of economies, severely impacted banks and stocks markets, and led to significant decreases in the global flows of capital. Within this context, the purpose of this paper is to report on the performance of Jordanian banks in 2020, and examine the determinants of their performance.

Methodology- To realize the objective of this paper, the performance of all listed Jordanian banks (13) during the period 2010-2020 is examined in terms of their return on assets (ROA) and net interest margin (NIM). Using the Seemingly-Unrelated Regression (SUR), ROA and NIM are regressed on a set of variables including equity capital, bank expenses and size, income diversification, loan loss provisions, lending to the government, and economic growth.

Findings- The 2020 financial statements show that the profits of Jordanian banks (return on assets) have decreased from 1.43 percent in 2019 to 0.74 percent in 2020 , or by about 48 percent. This decrease in profits was largely due to the increase in loan loss provisions. As far as the econometric results are concerned, it is interesting to note that loan loss provisions impact bank profitability in a negative and significant manner. On average, however, the cost of loan loss provisions are passed-on, at least partly, to bank customers in the form of wider costs of financial intermediation. Conclusions- While much of the determinants of bank performance are applicable to the Jordanian banks, it is encouraging to note that thes banks have managed to finish the 2020 financial year in a good shape. Indeed, this is the result of their strong financial positions that enabled them to increase their loan loss provision by large proportions.

Keywords: Jordan, banks, profitability, net interest margin, bank size, seemingly-unrelated regression. JEL Codes: G20, G21, G24

\section{REFERENCES}

Al-Homaidi, E., Almaqtari, F., Yahya, A. and Khaled, A. (2020). Internal and external determinants of listed commercial banks' profitability in India: Dynamic GMM approach. International Journal of Monetary Economics and Finance, 13: 34-67.

Al-Homaidi, E., Tabash, M., Farhan, N. and Almaqtari, F. (2018). Bank-specific and macro-economic determinants of profitability of Indian commercial banks: A panel data approach. Cogent Economics \& Finance, 6: 1-26.

Allen, L. (1988). The determinants of bank interest margins: A note. Journal of Financial and Quantitative Analysis, 23: $231-235$.

Almaqtari, F. A., Al-Homaidi, E. A., Tabash, M. I., \& Farhan, N. H. (2019). The determinants of profitability of Indian commercial banks: A panel data Approach. International Journal of Finance and Economics, 24: 168-185.

Angbazo, L. (1997). Commercial bank net interest margins, default risk, interest rate risk and off balance sheet banking. Journal of Banking and Finance, 21: 55-87.

Bagehot, W. (1873), Lombard Street, Homewood, IL: R. Irwin 1962 edition. 
Batten, J. and Vo, X. (2019). Determinants of bank profitability - Evidence from Vietnam. Emerging Markets Finance and Trade, 55: 417-1428.

Caliskana, M. and Lecunab, H. (2020). The determinants of banking sector profitability in Turkey. Business and Economics Research Journal, 11: 161167.

Chortareas, G. and Girardone, G. (2011). Banking sector performance in Latin America: Market power versus efficiency. Review of Development Economics, 15: 307-325.

Demirguc-Kunt, A. and Huizinga, H. (1999). Determinants of commercial bank interest margins and profitability: Some international evidence. World Bank Economic Review, 13: 379-408.

Demirguc - Kunt, A. and Huizinga, H. (2001). Financial structure and bank profitability, in financial structure and economic growth: A cross-country comparison of banks, markets, and development. Cambridge and London: MIT Press.

Farooq, M., Khan, S., Siddiqui, A., Khan, M. and Khan, M. (2021). Determinants of profitability: A case of commercial banks in Pakistan. Humanities and Social Sciences Reviews, 9: 1-13.

Fungacova, Z. and Poghosyan, T. (2011). Determinants of bank interest margins in Russia: Does bank ownership matter? Economic Systems, 3: 481495.

Gurbuz, A., Yanik, S. and Ayturk, Y. (2013). Income diversification and bank performance: Evidence from Turkish banking sector. Journal of BRSA Banking and Financial Markets, 7: 9-29.

Hashem, H. (2016). Determinants of Egyptian banking sector profitability: Time series analysis from 2004-2014. International Journal of Business and Economic Sciences Applied Research, 9: 73-78.

Helhel, Y. (2015). Evaluating the performance of the commercial banks In Georgia. Research Journal of Finance and Accounting, 5: $146-156$.

Ho, T., Saunders, A. (1981). The Determinants of bank interest margins: Theory and empirical evidence. Journal of Financial Quantitative Analysis, 16: 581-600.

Jadah, H., M. Alghanimi, M., Al-Dahaan, N. and Al-Husainy, N. (2020). Internal and external determinants of Iraqi bank profitability. Banks and Bank Systems, 15: 79-93.

Le, T. and Ngo, T. (2020). The determinants of bank profitability: A cross-country analysis. Central Bank Review, 20: 65-73.

Le, T. and Nguyen, D. (2020). Capital structure and bank profitability in Vietnam: A quantile regression approach. Journal of Risk and Financial Management, 13: 168-172.

Levine, R. (2004). Finance and growth: Theory and evidence. NBER Working Paper No. 10766.

Lucas R. (1988). On the mechanics of economic development. Journal of Monetary Economics, 22: 3- 42.

McShane, W. and Sharpe, G. (1985). A time series / cross section analysis of the determinants of Australian trading bank loan / deposit interest margins: 1962-1981. Journal of Banking and Finance, 9: 115-136.

Naceur, S. and Omran, M. (2011). The effects of bank regulations, competition, and financial reforms on banks' performance. Emerging Markets Review, 12: 1-20

Nassar, K., Martinez, E and Pineda, A. (2015). Determinants of banks' Net interest margins in Honduras. IMF Working Paper No. 14/163.

Omet, G. (2019). Income diversification and bank performance: The Jordanian case. Journal of Business, Economics and Finance, 8: 28-37.

Saif-Alyousfi, A. (2020). Determinants of bank profitability: Evidence from 47 Asian countries. Journal of Economic Studies, 47: 1-17.

Saunders, A. and Schumaker, L. (2000). The determinants of bank interest rate margins: An International Study. Journal of International Money and Finance, 19: 813-832.

Shami, M., Omet, G., Bino, A. and Abu-Khalaf, B. (2015). Banks offer lottery prices: What are the implications? Journal of Management, Marketing and Logistics, 2: 2015-2220.

Schumpeter, J. (1934). The theory of economic development, 1912, Translated by Redvers Opie. Harvard University Press, Cambridge, USA.

Topak, M. and Tırmandıoglu T. (2017). Bank specific and macroeconomic determinants of bank profitability: Evidence from Turkey. International Journal of Economics and Financial Issues, 7: 574-584.

Trujillo-Ponce, A. (2013). What determines the profitability of banks? Evidence from Spain. Accounting and Finance, 53: 561-586.

Yaseen, H., Omet, G. and Kahmash, F. (2015). On the entry of foreign banks: The Jordanian experience. International Journal of Economics and Finance, 7: 278-282. 